Paper ID \#20094

\title{
Evidence-Based Reasoning in a Kindergarten Classroom through an Inte- grated STEM Curriculum (Fundamental)
}

\author{
Dr. Anastasia Marie Rynearson, Purdue University, West Lafayette (College of Engineering)
}

Anastasia Rynearson is a recent $\mathrm{PhD}$ graduate of Engineering Education at Purdue University. She received a B.S. and M.Eng. in Mechanical Engineering at the Rochester Institute of Technology. Her teaching experience includes outreach activities at various age levels as well as a position as Assistant Professor in the Mechanical Engineering Department at Kanazawa Technical College. Her current research interests focus on early P-12 engineering education and identity development.

\section{Prof. Tamara J. Moore, Purdue University, West Lafayette (College of Engineering)}

Tamara J. Moore, Ph.D., is an Associate Professor in the School of Engineering Education and Director of STEM Integration in the INSPIRE Institute at Purdue University. Dr. Moore's research is centered on the integration of STEM concepts in K-12 and postsecondary classrooms in order to help students make connections among the STEM disciplines and achieve deep understanding. Her work focuses on defining STEM integration and investigating its power for student learning. Tamara Moore received an NSF Early CAREER award in 2010 and a Presidential Early Career Award for Scientists and Engineers (PECASE) in 2012.

\section{Kristina Maruyama Tank, Iowa State University}

Kristina M. Tank is an Assistant Professor of Science Education in the School of Education at Iowa State University. She currently teaches undergraduate courses in science education for elementary education majors. As a former elementary teacher, her research and teaching interests are centered around improving elementary students' science and engineering learning and increasing teachers' use of effective STEM instruction in the elementary grades. With the increased emphasis on improved teaching and learning of STEM disciplines in K-12 classrooms, Tank examines how to better support and prepare pre-service and in-service teachers to meet the challenge of integrating STEM disciplines in a manner that supports teaching and learning across multiple disciplines. More recently, her research has focused on using literacy to support scientific inquiry, engineering design, and STEM integration.

\section{Mrs. Elizabeth Gajdzik, Purdue University, West Lafayette (College of Engineering)}

Elizabeth Gajdzik is the Assistant Director of the INSPIRE Research Institute for Pre-College Engineering in the School of Engineering Education at Purdue University. She received both her B.S. in Interdisciplinary Studies with a specialization in mathematics and M.S.Ed. in Curriculum and Instruction with an emphasis in mathematics education from Baylor University. Prior to her work at INSPIRE, Elizabeth was a district curriculum math specialist in San Antonio, TX and a middle school mathematics teacher at a Title 1 school in Waco, TX. 


\section{Evidence-Based Reasoning in a Kindergarten Classroom through an Integrated STEM Curriculum (Fundamental)}

\section{Background}

Engineering is no longer an uncommon addition to P-12 classrooms. Basic engineering guidelines and practices have been suggested for precollege students in a number of reports and articles, including the Framework for K-12 Science Education: Practices, Crosscutting Concepts, and Core Ideas. ${ }^{1}$ Among the eight essential practices in science and engineering is the practice of engaging in argument from evidence, often called argumentation. This practice allows students to design the best possible solution to meet the needs of a client from a variety of possible solutions. The use of these arguments in an engineering context has been called evidence-based reasoning $(\mathrm{EBR}){ }^{2}$

EBR may also be a hallmark of high-quality engineering design. "Tinkering" is commonly seen in engineering design, especially in pre-college engineering activities. While it is a valuable skill, tinkering is not engineering. EBR can be used to ensure that students are providing evidence for their design decisions, not just tinkering until they find a reasonable solution. Minimal research about EBR or argumentation in engineering-specific contexts is currently available, especially in the early grades. ${ }^{2}$

The purpose of this research is to explore engineering practices in Kindergarten classrooms during an integrated curriculum. The research question is: How do Kindergarten students engage in evidence-based reasoning during an integrated STEM and literacy curriculum?

\section{Framework}

Evidence Based Research is built on scientific argumentation. ${ }^{2}$ Both engineering and science incorporate forms of argumentation, or making claims and backing up those claims with evidence and/or additional forms of reasoning to support the initial claim. Argumentation as a practice is noted in the Framework for K-12 Science Education: Practices, Crosscutting Concepts, and Core Ideas as an essential practice and the difference between the way it is used in science and engineering is noted. ${ }^{1}$ Rather than describing natural phenomena as scientists do, engineers use arguments to justify design decisions and rationales for trade-offs. More specifically, evidence-based reasoning is built on Toulmin's Argument Pattern, one style of scientific argumentation that incorporates many aspects common to multiple models of scientific argumentation. ${ }^{2}$ While Tolumin's full description of the components of argumentation is noted below, for this study, any claim followed by an explanation or evidence to support that claim is considered developmentally appropriate EBR in a Kindergarten classroom. 


\section{Toulmin's Argument Pattern ${ }^{3}$}

The Evidence-Based Reasoning model is based on Toulmin's Argument Pattern, or TAP. There are six main components to argumentation according to TAP, claims, data, warrants, qualifiers, rebuttals, and backing.

Claim - a claim is the statement that was being argued

Data - facts or evidence used to support the claim

Warrants - logical statements connecting the data to the claim

Qualifiers - statements proposing conditions where the argument holds true

Rebuttals - counter-arguments for when the general argument does not hold true

Backing - statements that support the warrants but not the claim itself

Developmentally appropriate EBR in a Kindergarten classroom involves a claim, or an assertion regarding an aspect of the engineering solution that is being designed, and a connected statement to support the claim. The connected statement can either be part of the initial description (e.g. "I will choose $\mathrm{X}$ for my design because $\mathrm{Y}$ ") or can be a later statement to support the initial claim, often in response to asking the student why they have chosen what they have chosen. Connected statements to support the claim can include data, often evidence from personal experiences or classroom investigations, warrants, connecting data to the claim but not necessarily providing the facts or evidence itself, qualifiers, bounding the claim to specific circumstances, rebuttals, arguments to support the claim in the face of qualifiers, or backing, statements supporting aspects of the argument but not the claim itself. Any attempted use of evidence or reasoning to support the claim is considered an act of EBR, even if the evidence is incorrect or the reasoning is specious. In EBR, a design decision is also considered a claim, where the underlying claim is that the design decision meets the client's criteria and constraints.

\section{Methods}

This study uses thematic analysis of video data as the primary source of data. The published lesson plans are a secondary source of data used to understand where EBR practices should be expected throughout the lessons. The two sources are combined for a greater understanding of how EBR practices are seen throughout an integrated STEM unit in Kindergarten classrooms.

\section{Participants}

Three Kindergarten classrooms teaching the same integrated STEM unit, Designing Paper Baskets, were involved in this study. Each class was taught by a white female teacher. Each classroom contained a different number of students; data was collected from 32 students in accordance with IRB \#1401014380. Any names used throughout this study are pseudonyms, given for ease of reading.

\section{Context}


A ten-lesson integrated curriculum incorporating literacy and STEM lessons was developed for use in Kindergarten classrooms. Four primary components set this curriculum apart from other commonly-implemented engineering lessons: 1) engineering design as the interdisciplinary glue, 2) realistic engineering contexts to promote student engagement, 3) high-quality literature to facilitate meaningful connections and 4) instruction of specific STEM content within an integrated approach. ${ }^{4}$ This curriculum is the context for observing evidence of developmentally-appropriate engineering practices in Kindergarten students. In addition to the five lessons shown in Table 1, there is an introductory lesson where engineering, the engineering design process, and the overarching engineering challenge is introduced.

Table 1. PictureSTEM Designing Paper Baskets curriculum

\begin{tabular}{|c|c|c|c|c|c|}
\hline & Lesson 1 & Lesson 2 & Lesson 3 & Lesson 4 & Lesson 5 \\
\hline $\begin{array}{l}\mathrm{L} \\
\mathrm{i} \\
\mathrm{t} \\
\mathrm{e} \\
\mathrm{r} \\
\mathrm{a} \\
\mathrm{c} \\
\mathrm{y}\end{array}$ & $\begin{array}{l}\text { Book: } \\
\text { If you Find a } \\
\text { Rock } \\
\text { Strategy: } \\
\text { Identify } \\
\text { beginning and } \\
\text { ending sounds } \\
\text { of words }\end{array}$ & $\begin{array}{l}\text { Book: } \\
\text { I Get Wet (part } \\
\text { 1) } \\
\text { Strategy: } \\
\text { Blend three } \\
\text { letters in sound } \\
\text { boxes that } \\
\text { represent the } \\
\text { phonemes of a } \\
\text { word }\end{array}$ & $\begin{array}{l}\text { Book: } \\
\text { I Get Wet (part } \\
\text { 2) } \\
\text { Strategy: } \\
\text { Summarize text } \\
\text { using interactive } \\
\text { writing }\end{array}$ & $\begin{array}{l}\text { Book: } \\
\text { Pattern Fish } \\
\text { Strategy: } \\
\text { Identify } \\
\text { rhyming words } \\
\text { and patterns }\end{array}$ & $\begin{array}{l}\text { Book: } \\
\text { Rocks, Jeans } \\
\text { and Busy } \\
\text { Machines } \\
\text { Strategy: } \\
\text { Summarize } \\
\text { narrative text } \\
\text { with interactive } \\
\text { sentence writing }\end{array}$ \\
\hline $\begin{array}{l}\mathrm{S} \\
\mathrm{T} \\
\mathrm{E} \\
\mathrm{M}\end{array}$ & $\begin{array}{l}\text { Identify the } \\
\text { properties of } \\
\text { the paper } \\
\text { samples and } \\
\text { sort using those } \\
\text { properties. }\end{array}$ & $\begin{array}{l}\text { Learn about } \\
\text { properties of } \\
\text { paper when wet } \\
\text { and dry through } \\
\text { the water drop } \\
\text { test, wax and } \\
\text { water test. }\end{array}$ & $\begin{array}{l}\text { Test the strength } \\
\text { of dry/wet paper } \\
\text { with rocks. }\end{array}$ & $\begin{array}{l}\text { Identify and } \\
\text { create patterns, } \\
\text { explore } \\
\text { repeating and } \\
\text { alternating } \\
\text { patterns, } \\
\text { identify } \\
\text { weaving } \\
\text { pattern for } \\
\text { basket plan. }\end{array}$ & $\begin{array}{l}\text { Test baskets } \\
\text { with wet and } \\
\text { dry rocks and } \\
\text { communicate } \\
\text { solution to } \\
\text { clients. }\end{array}$ \\
\hline
\end{tabular}

\section{Document Analysis}

Evidence-based reasoning is an engineering practice that is expected to emerge during high-quality engineering interventions. In early grades such as Kindergarten, students need to be guided to use EBR in developmentally appropriate ways. The integrated STEM unit, Designing Paper Baskets, encourages student use of EBR through teacher-guided activities and engineering design content. To better understand how students' use of EBR is seen throughout the ten lessons, a document analysis of the entire Designing Paper Baskets unit was done to note where 
teacher-guided EBR was expected to be present and where students were expected to organically use EBR (e.g. during the plan and decide phases of engineering design) ${ }^{5}$

\section{Thematic Analysis}

Initially, all researchers reviewed a selected subset of the video data. ${ }^{6}$ Using the engineering design process (Figure 1) as a framework, researchers inductively and deductively created a coding scheme to analyze the video data. After the coding scheme was developed, all video data was analyzed by two researchers. Further analysis of the data allowed for additional open coding of unexpected results such as EBR. While other themes have been found, this study will focus strictly on the examples of evidence-based reasoning observed in the video data. EBR for this study includes instances where a student makes a claim pertaining to the engineering design challenge and backs that claim up with evidence or justification of some sort. Examples of scientific argumentation, commonly seen when explaining the results of an experiment or discussing natural phenomena, were not counted. In a few instances, multiple students made a claim in chorus and some followed up with data or warrants. Each student's response was counted as a separate instance of EBR.

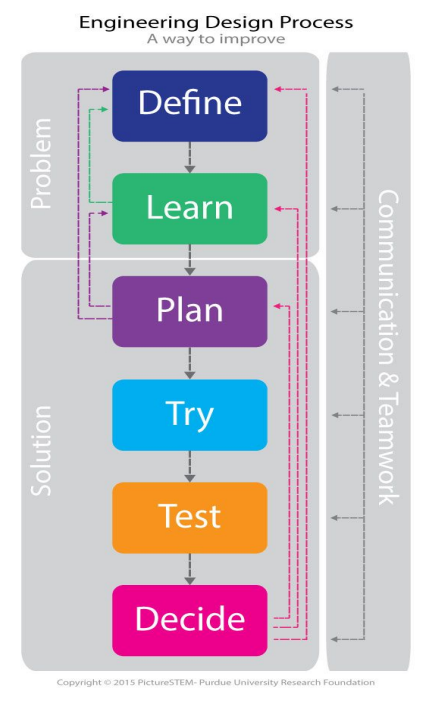

Figure 1. Engineering Design Process

\section{Triangulation}

Finally, the two initial analyses are triangulated to compare the data. ${ }^{7}$ The thematic analysis of classroom observations is compared with the document analysis of the curriculum to understand where teacher-guided EBR was expected to be present, where students were expected to organically use EBR (e.g. during the plan and decide phases of engineering design), and where students unexpectedly used EBR within the lessons. Examples of EBR are provided to support the results and to illustrate the ways that Kindergarten students engage in EBR. 


\section{Results/Discussion}

\section{Document Analysis}

In reviewing the curriculum, there were places in each STEM-focused lesson where EBR was expected to occur, as seen in Table 2. Expected occurrences of EBR were noted when the curriculum instructed the teacher to ask the student to explain the reasoning behind any choice, generally through the use of words like "why" and "discuss" or "explain".

Table 2. Evidence-based reasoning expected in Designing Paper Baskets curriculum

\begin{tabular}{|l|l|l|l|}
\hline Lesson & Source & EDP & Excerpt \\
\hline 1B & Teacher & $\begin{array}{l}\text { Learn } \\
\text { (Plan) }\end{array}$ & $\begin{array}{l}\text { Once students have made their selection, have them discuss } \\
\text { with their partners what paper they selected and why. }\end{array}$ \\
\hline 2B & Teacher & $\begin{array}{l}\text { Learn } \\
\text { (Plan) }\end{array}$ & $\begin{array}{l}\text { Ask: Which papers do you think will be best for designing } \\
\text { Max's basket? Why? }\end{array}$ \\
\hline 3B & Teacher & $\begin{array}{l}\text { Learn } \\
\text { (Plan) }\end{array}$ & $\begin{array}{l}\text { Listen as students share their ideas for which paper should be } \\
\text { used for Max's basket and why. }\end{array}$ \\
\hline 4B & Teacher & Plan & $\begin{array}{l}\text { In pairs, have students discuss the two options for their baskets } \\
\text { and mark their choices on the BLM*. }\end{array}$ \\
following (prompt students as necessary): \\
$\bullet$ Why they chose the papers they did? \\
Plan \\
5B
\end{tabular}

* BLM: Black Line Master, also known as student worksheets

In every lesson, there is an example of developmentally-appropriate scaffolding where the teacher asks the students to consider the engineering design and to explain their choices or claims, in other words engaging in EBR through providing data, warrants, qualifiers, rebuttals, or 
backing for their claims as defined in the TAP model. As expected from an earlier study, the majority of EBR was seen in Plan and Decision segments of the design challenge. ${ }^{2}$ Even when the overarching step of the design process for the entire lesson was Learn, as in lessons $1 \mathrm{~B}, 2 \mathrm{~B}$, and 3B, EBR was expected when the lesson was connected back to the engineering challenge through considering how the information they had learned could contribute to the final design, or the Plan stage.

\section{Video Analysis}

Each instance of EBR by students was noted in the videotaped lessons. Lessons where EBR occurred in each classroom are shown in Table 3.

Table 3. Evidence-based reasoning seen in Designing Paper Baskets curriculum by classroom

\begin{tabular}{|l|l|l|l|l|l|l|l|l|l|l|l|}
\hline & Intro & $1 \mathrm{~A}$ & $1 \mathrm{~B}$ & $2 \mathrm{~A}$ & $2 \mathrm{~B}$ & $3 \mathrm{~A}$ & $3 \mathrm{~B}$ & $4 \mathrm{~A}$ & $4 \mathrm{~B}$ & $5 \mathrm{~A}$ & $5 \mathrm{~B}$ \\
\hline Class 1 & & & & & & $\mathrm{X}$ & & & & & $\mathrm{X}$ \\
\hline Class 2 & $\mathrm{X}$ & & $\mathrm{X}$ & & $\mathrm{X}$ & & $\mathrm{X}$ & & $\mathrm{X}$ & & $\mathrm{X}$ \\
\hline Class 3 & & & & & $\mathrm{X}$ & & & & $\mathrm{X}$ & & $\mathrm{X}$ \\
\hline
\end{tabular}

Evidence-based reasoning occurred in every STEM lesson (B lessons). EBR did not occur in every classroom in every STEM lesson. EBR also occurred in one literacy lesson in one classroom.

Some students used the results of their STEM lessons as evidence and reasoning for their claims. This was most often seen when students suggested using wax paper as the material to choose; one of the design constraints was that the baskets must hold wet and dry rocks. Wax paper was recognized as very successful in holding wet rocks. Students in all classrooms recognized this and used it as evidence for choosing wax paper as the material that should be used in their basket design.

Class 1, Lesson 3A: "I know which kind of paper we should use...wax! It holds wet and dry!"

Class 2, Lesson 2B: "[Use] Wax [paper]! It’s tough!"

Class 2, Lesson 5B: "No [our basket will not break]. Because we got wax paper."

Class 3, Lesson 2B: Student raised hand to indicate they would recommend wax paper and was asked why. "It [the water] slipped off."

Students did not always use scientific evidence to back up their claims. In Class 2, Lesson 4B, students explained their design choices using both evidence and personal preference. Multiple students explained their choice of wax paper by noting its strength. One student chose tissue paper "because I thought there might be some colors and I like how it feels." Another student justified their choice of the ABBABB pattern because "it looks like a creeper face." Some students even made claims that went against the findings of their scientific experiments, such as 
the student in Class 2 during Lesson 1B who felt that tissue paper would be a good choice for the basket design as "if it gets wet it won't even rip." While students in Class 2 often justified their design choices by talking about the strength of the paper, students in Class 3 focused on a different design specification requiring the basket to "look nice." In Lesson 5B, one student justified their team's choice to use tissue paper because "We like tissue paper. It makes it look very pretty." Another group chose "Construction and tissue. We think they look like a good pattern together."

Using the TAP framework, nearly all of the examples of EBR would include data and/or warrants to support the students' claim. One student in Class 1 used a qualifier during lesson 5B, noting that their construction paper basket was a good prototype "but on the other side it kind of falled out."

Overall, there were 35 instances of EBR. Twenty-nine of these instances happened when students added evidence to their claims after the teacher asked the student to explain their reasoning. For this sample of Kindergarten students, $83 \%$ of EBR was induced by the teacher, showing that EBR can occur in this age group however it is developmentally appropriate to scaffold their learning through asking the students to explain their reasoning.

\section{Triangulation}

Based on the document analysis, EBR was expected to be found in every STEM-focused (B) lesson. EBR was found in every STEM-focused lesson in one classroom, Class 2. It was seen in every STEM-focused lesson in at least one classroom and additional instances of EBR were seen in some of the literacy-focused lessons and the introductory lesson.

From the document analysis, it was expected that the majority of EBR would be teacher-driven, prompted by the teacher asking the students to explain their claims. Overall, $83 \%$ of EBR instances were teacher-driven. It was expected that all of the occurrences of EBR before Lessons $5 \mathrm{~B}$ and $6 \mathrm{~B}$ would be teacher-driven, however that was not the case.

Student-driven EBR was expected in Lessons 5B and 6B, when students were discussing their design with their partners and/or explaining their choices to the entire class. While students did defend their design choices (claims), they often did not use evidence or justification for engineering decisions. Rather, when there were disagreements, they argued with partners, claiming their choice should be used without justification.

Beyond expected teacher- and student-driven EBR as expected from the curriculum, there was the possibility for additional instances of EBR throughout the classroom implementation. There were few examples where students organically engaged in EBR. Overall, they were comfortable making claims but rarely provided evidence to back up their claims.

While reading the book I Get Wet in Class 1, one student excitedly connected the book's discussion of wax paper to the engineering project, "I know which kind of paper we should use! Wax! It holds wet and dry!" 
During the introductory lesson in Class 2, one student was already forming engineering solutions while the class was discussing the criteria and constraints set forth by the clients, Max and Lola. "It needs to be metal paper. They can find some dry and wet rocks and some, if it's papers like these (holds up laminated copy paper), if it's regular paper, the wet rocks will get it wet and they fall out because it's strong and it's wet. It needs to be metal." The student saw a problem with using paper for collecting wet rocks and explained their rationale for using metal to make the basket.

\section{Conclusions}

Students in grades as early as Kindergarten are able to engage in engineering practices, specifically evidence-based reasoning. In EBR for Kindergarten students, the most important aspect is asking "Why?" Throughout the curriculum, students are very willing to make claims but a claim alone does not create an argument. Teachers that followed up by asking their students to support their claims had higher instances of EBR overall as well as higher numbers of lessons where EBR occurred. Asking Kindergarteners why they are making the claims they are making helps them to develop their evidence-based reasoning skills.

The findings here can influence teacher professional development and interactions with P-12 students in formal and informal settings. Argumentation, and by extension, evidence-based reasoning, are important skills for students to learn. Teacher professional development providers should highlight the importance of asking students to explain their design decisions when engaging in engineering activities. Those facilitating engineering activities, whether in formal classrooms, outreach programs, or even parents, should also be aware that young students are able to engage in engineering practices such as evidence-based reasoning. This study also points to an important scaffolding tool to help young students build their EBR skills, using the question "Why?"

\section{Limitations}

This study followed three classrooms during a pilot implementation of an integrated STEM and literacy curriculum for Kindergarten students. Teachers were using the curriculum for the first time and the curriculum was not in its final state. Classroom 1 did not have the full implementation video recorded so may have had additional instances of EBR in the classroom at other times.

\section{Acknowledgements}

The material presented is based upon work supported by the National Science Foundation under grants EEC-1442416 and DRL-1543175. Any opinions, findings and conclusions or recommendations expressed in this material are those of the authors and do not necessarily reflect the views of the National Science Foundation 


\section{References}

[1] National Research Council. (2012). A framework for K-12 science education: Practices, crosscutting concepts, and core ideas. Washington, DC: The National Academies Press.

[2] Mathis, C. A., Siverling, E. A., Glancy, A. W., Guzey, S. S., \& Moore, T. J. (2016).

Students' use of evidence-based reasoning in K-12 engineering: A case study (fundamental)

Paper presented at 2016 ASEE Annual Conference \& Exposition, New Orleans, LA.

10.18260/p.25943

[3] Toulmin, S. E. (1958). The uses of argument. New York, NY: Cambridge University

Press.

[4] Tank, K. M., Moore, T. J., Dorie, B. L., Gajdzik, E., Sanger, M. T., Rynearson A. M., Mann, E. F. (in press). Engineering in early elementary classrooms through the integration of high-quality literature, design, and STEM $+\mathrm{C}$ content.

[5] Bowen, G. A. (2009). Document analysis as a qualitative research method. Qualitative Research Journal, 9(2), 27-40.

[6] Derry, S. J., Pea, R. D., Barron, B., Engle, R. A., Erickson, F., Goldman, R., ... \& Sherin, B. L. (2010). Conducting video research in the learning sciences: Guidance on selection, analysis, technology, and ethics. The Journal of the Learning Sciences, 19(1), 3-53.

[7] Creswell, J. W. (2008). Research design: Qualitative, quantitative, and mixed methods approaches. Los Angeles, CA: Sage Publications, Incorporated. 